\title{
Invasion as a Practice: Understanding State Behavior in Putin's Russia
}

\author{
Dylan Stent* AND Eugene LeE (ASKhat F. SAFIUllin) ${ }^{* *}$
}

Throughout 2014 and 2015 Russia annexed Crimea and helped secessionist forces in Eastern Ukraine. However, interventions are nothing new to modern Russia. In 2008 Russia invaded Abkhazia and South Ossetia unilaterally after the Russo-Georgian War. The question arises: what drives Russia's leaders, namely President Putin, to acquire new territories? Normative theories have proven inadequate at predicting Putin's decisionmaking in the Commonwealth of Independent States (CIS), and thus, this paper analyzes these developments through the lens of practice theory. This paper proposes that Putin's innate learning during his upbringing, and during his time in the Комите́т государственной безопасности (KGB), has tempered his diplomatic practice. Surrounding himself with likeminded policymakers, and embedding a carefully crafted propaganda image, we call it a new Putinism, has prevailed in Russian diplomatic practice. This proposed concept is based on five premises: Russian ethno-centrism, not being scared of the global West, secrecy, disdain for multilateral institutions, and the creation of a Russian sphere of influence. The paper concludes that Russia is likely to continue annexing close-by lands as a way of legitimizing the regime of President Putin.

Keywords: Russia, CIS, Georgia, Crimea, Ukraine, Practice Theory

* Policy Analyst, New Zealand Defence Force, New Zealand;

E-mail: dylan.stent@gmail.com

** Adjunct Professor, Sungkyunkwan University, Seoul, South Korea;

E-mail: mreulee@gmail.com

DOI: 10.16934/isr.17.2.201612.101 


\section{INTRODUCTION}

Who is Vladimir Putin? A Tsar? A Communist Dictator? A new Hitler? Putin has been called many things due to his foreign policy while he has been President of Russia. Whatever the label has been put on Putin, it is important to study his diplomatic behavior in light of recent developments in the region. However, normative studies (realist, liberal or otherwise) have proven insufficient at explaining many of Putin's actions. The following qualitative study endeavors to answer one simple question: why has Russia invaded and destabilized parts of Georgian and Ukrainian territories? The traditional schools of International Relations (IR) suffer from what Pouliot terms "representational bias," as they rely on the use of rational calculations. The crux of representational bias lays in "rational choice theory and its tendency to deduce from the enacted practice (opus operatum) and its mode of operation (modus operandi)." Thus, scholars mistake the outcome of practice for its process. Rational choice proponents rationalize actions post hoc, rather than explaining actions as they occur. International actors (states or individuals) do not necessarily have the information to solve an issue at that time and instead rely on innately learnt practice. As a result, "these hunches take precedence over rational calculations" (Pouliot 2010, 17). IR theory cannot fully explain why this occurs. As current IR scholarship is unable to explain when, why, and how a regional conflict turns into a violent one, we propose applying a rationale put forward by Vincent Pouliot (Pouliot 2010, 2008), the initial roots of which lay in Pierre Bourdieu's theory of practice. Using practice theory provides an interesting examination of recent events in the region and may help policymakers and academics better understand the region.

This paper examines how diplomats and political leaders (agents) bring inarticulate knowledge when conducting regional diplomacy, in particular regional security diplomacy. To explain why dynamics of regional behavior develops in that particular way, the paper is divided into four sections. The first section is an exploration of existing literature on practice theory and critical definitions, and also why practice theory may be effective at explaining Russia's approach in expanding its influence into nearby states. The second section will look at what Putinism has meant to scholars in the IR field. The third section will explore what we call New Putinism. The final section will discuss Russia's behavior in the 2008 Russo-Georgian War and the invasion of Crimea in 2014. The paper will conclude with the idea that Western economic sanctions have had no impact on the conduct of Russia's foreign policy. The annexation of Crimea and probable developments in South Ossetia, Abkhazia and parts of Eastern Ukraine, are due to a new policy of invasion by President Putin. As a result of this, the creation of a new Russian Sphere of influence is likely to bring more instability, with an increased likelihood of further annexations. 


\section{LITERATURE REVIEW}

Practice theory is based on concepts of field, habitus and doxa (Pouliot 2010, 46). The doxa includes "all that is accepted as obvious, in particular the classifying schemes which determine what deserves attention and what does not" (Pouliot $2008,275)$. The position of each actor is tempered by interaction between the agents' habitus, doxa and their cultural and social disposition. Diplomatic habitus is a "set of regular traits which dispose its bearers to work in a certain way, making diplomacy possible" (Pouliot 2010, 46). Habitus is historical, where history is turned into second nature and is thus actualized in the present. It is proposed that when peaceful or non-violent conflict is present a habitual doxic (peaceful and effective) relationship is born. However, when it fails, a hysteresis (not peaceful and ineffective) situation occurs. Thus, we argue, in the CIS region, at least in Georgia and Ukraine, a serious hysteresis relationship has developed due to Russian involvement.

A field is a setting where diplomats and state actors including Presidents (what Bourdieu calls agents) and their social positions, or symbolic positions, are located. A field has three dimensions: relations of power, objects of struggle, and taken-for-granted rules (Pouliot 2010, 46). They are comprised of unequal positions, where some agents dominate others through historically constructed capitals, be it economic or social. Fields can be seen as relatively autonomous from one another as they have been characterized by certain struggles that have been socially and historically constructed.

Agents in a specific order accept the doxa-the operational assumptions, rules and norms-that are utilized by the various actors. Bourdieu proposed doxa is the experience by which "the nature and social world appears as self-evident" (Pouliot 2010, 46). Crucially, this idea of doxa is in opposition to constructivism. The future anticipated by social agents is "rooted in perceptions of past and present conditions, and harmonized with the 'objective' possibilities in the structure for the agent. One cannot, as Bourdieu accused Jean-Paul Sartre and Alain Touraine of doing, attribute 'conscious and deliberate intention' to social agents" (ReedDanahay 2005, 109). Therefore, a constructivist analysis is highly limited. A specific Russian method of diplomacy may not exist purely through conscious creation, but has been instilled in Putin and others through innate practice. Diplomacy is not a purely well thought out rational action, instead these actions show "relationships of domination where all parties internalize the reigning symbolic order imposed by the dominant actors" (Jackson 2005, 17). As this becomes internalized, agents learn how to act appropriately when they interact with other states. Practical sense becomes a self-regulating mechanism where preferences are in line with the arrangement and rules of the game. The result is a situation where, as Pouliot puts it, an orchestra exists without a conductor (Pouliot 2010). This is not 
what is currently occurring in the CIS and Ukraine.

When the relationship between the field and habitus is broken, the diplomatic pattern that was created falters. Bourdieu calls this phenomenon of disconnection between positions and dispositions "hysteresis" (Pouliot 2010, 46). Hysteresis is captured in diplomacy when the interplay between habitus and field is adapted inadequately to a situation. Thus, they are not acting in harmony with common sense. This can occur when a state tries to engage in a diplomatic activity not congruent with the habitus of a particular group of states. Clearly, this has been the case in the 2008 Russo-Georgian War and the 2014 Crimea Conflict. The habitus, or at least the Western habitus of diplomacy, in the region has been broken by Russia's unilateral re-mapping of Europe.

Lastly, the easiest way to explain practice theory is using a real-life analogy. If we choose a game of baseball, a player will run around all bases when he hits a homerun. We must look at reasons for him doing it. He is not told to do this by an individual. Instead he does this due to a set of background habits, skills and dispositions. As soon as the batter realizes he has hit a home run he acts in a certain way (running around the bases). In diplomatic practice when practices are enacted everyday they become the background on which future social interactions are based. States become involved in regional governance not to consciously form a collective identity. They do so due to an inarticulate understanding that this is the practical way to act. Practice theory could therefore provide us with a new and unique way to look at whether Russian behavior in Georgia and Ukraine does in fact show us that they are now displaying a new great power habitus in the region. It could also highlight how actions by Georgia and Ukraine have been out of place and caused a rift in relations with Russia.

Much of IR orthodoxy revolves around "what agents think about at the expense of what they think from" (Pouliot 2010, 11). Pouliot contests that rational choice theorists place too high an "emphasis on representations and reflexive knowledge in explaining political action" (Ibid). Individuals simplistically "reflect on the most efficient way to achieve their ends." This is obviously not the case. "The three logics of social action that have the most currency in contemporary IR theory-the logics of consequences, appropriateness and arguing-suffer from a similar bias towards representational knowledge. Conscious representations are emphasized to the detriment of background knowledge-the inarticulate know-how from which reflexive and intentional deliberation becomes possible" (Ibid). This background becomes the heart of Pouliot's theory. Pouliot suggest "the practicality of diplomacy cannot be fully captured by detached, representational observation. At issue is not whether diplomats carefully ponder their options-they clearly do-but whether IR scholars appropriately take into account the considerably different context in which they do so" (Pouliot 2010, 15) From this perspective, the rationality of a certain situation may not be present. 
It is tempting, and easy, to explain Russian expansion in realist terms, as it appears to be a re-establishment of the Cold War. Russia is expanding its borders, and encroaching on other sovereign states. Scholars could, along with modern realism's main proponent John Mearsheimer, argue that the bipolarity of the Cold War ensured peace and stability in Europe (Mearsheimer 1990, 2001). When this bipolarity faltered the order of the region changed with war becoming ever more likely. Thus, states being rational entities would then pursue strategies for their own survival, essentially maintaining the status quo. However, what actually occurred was much different. After the Cold War Russia ceded power, but ultimately never lost its Great Power habitus (mindset) in the European continent. Realism is problematic as it does not account for ideas that are subjective and self-perceived rather than objective and tangible. Thus, explaining the present puzzle with this normative paradigm is unviable as it carries obvious analytical weaknesses. Using other IR approaches, we argue, would be more applicable for studying contemporary Russia's foreign policy.

Representational bias affects not only rational choice theory. Some popular strands of constructivism also fall into similar pitfalls. Constructivist approaches are constrained by ideas about how communities and actors must cultivate a collective identity of "we-ness" while consciously blurring the self and other. Although IR theorists like to lump theories together, many diverging constructivist theories exist. Pouliot proposes that James March and Johan Olsen's logic of appropriateness (March and Olsen 2010) deals "with norm and rule-based action as a matching of a situation to the demands of the position" (Pouliot 2010, 16). This asserts that on the one hand, appropriateness deals with the rules that are profoundly internalized. On the other hand, it is a reflexive process where agents must figure out what action is appropriate for a specific situation. Norm based action is reflected in some fashion, and thus practicality is largely ignored. Through reflection, an agent is presumed to make a "rational choice."

Many constructivist strands are externalist, construing externalist logic as social action. Keck and Sikkink's boomerang model is one such example (Keck and Sikkink 1998). State elites (and in turn the state as a whole) first conform to international norms through strategic calculation. Changes to internal thinking and preferences only change over time. A second externalist logic builds on the works of Habermas (Pouliot 2010, 18). Through communicative action, agents deliberate what norms are most appropriate for specific situations. This is similar to notions of social learning. Lastly, there are strands of externalist constructivism that concentrate on "cognitive processes that take place at the level of the human mind" (Ibid, 19). They insist that the human mind makes some agents more likely to break norms than others.

A number of constructivists make the judgment that the logic of appropriateness is essentially the same as internalizing taken for granted norms. The 
most famous of these is Wendt's discussion of internalization from the first degree to the third (Wendt 1999, 310-311). Wendt asserts that certain practices get pushed to the background and become taken for granted rather than objects of calculation. Norms are prescriptions of action that fade from rational thought, and turn into action. However, these assertions are still rife with representational bias. Pouliot sums this up nicely "the taken-for-granted knowledge that informs appropriateness necessarily begins as representational and conscious (Pouliot 2010, 21).”

This article takes a different approach at explaining Putin's behavior. The following will use the variable of a leader's innately learnt practice to explain Russia's state behavior. It is proposed that deeply ingrained ideas that have been continually practiced throughout Putin's life make Putin's Russia act in specific ways.

\section{CLASSICAL PUTINISM}

The rise of Russia over the last decade has been the object of much scholarship in the West. Initially this scholarship concentrated on how the region would treat a Russia they were depending on for gas. However, beginning in 2008 and gaining steam in 2014 after the invasion of Crimea, much scholarship has concentrated on Putinism, and the peculiar brand of governance he has practiced in the region and at home. However, the roots of Putinism are older than many may expect.

Analysis of Putinism began as early as the beginning of this millennium. Writing in 2001 Graeme P. Herd was debating with Mikhail Alekseev about what the meaning of Putinism entailed (Herd 2001). Herd proposed that Putinism differs from previous eras as he greatly reformed the federal system. This essentially resulted in a "recentralization" of the Russian polity. Within this a key tenant is constant: the center (Putin) was strengthened by the creation of seven federal districts, and regions were restricted as governors were removed from the Federation Council (Herd 2001, 109). This made them more susceptible to federal checks and criminal prosecution. Herd enquired whether this would "backslide from democracy to totalitarianism" (Ibid).

Daniel Beer proposes "What has come to be known as 'Putinism' has involved the centralization of political and economic power, the emasculation of parliamentary politics, the muzzling of the media, a return to the rhetoric of Great Russian nationalism and a bullying interference in the affairs of neighboring states in what the Russians call the "near abroad"" (Beer 2009). Beer suggests this new authoritarianism is the result of a powerful clique of siloviki. The siloviki are former members of the intelligence services (most famously the KGB) who hold important positions of power in Russia. Critics say this influence has taken over and a "KGB Spirit" has taken hold (Ibid).

With increased tension in the region Putin has been compared to former 
Soviet dictators, primarily Stalin and Brezhnev. Reddaway (2011) proposed Putin has many similarities to Brezhnev but is ultimately a different leader. Reddaway proposes that Putin's Russia is similar to that of China under Deng Xiaoping. Putin has carried out economic reform that has enriched the ruling elite, whilst simultaneously blocking any significant reform and convincing the public that change will adversely affect the populous. One way of convincing the public has been through invasion and annexation, as will be explored later in this paper. Similarly, Lev Gudkov proposes that the Putinism is a "particular type of posttotalitarianism in which the political police wields power on behalf of the private interests of bureaucratic clan or corporations" (Gorenburg 2011, 4). Gudkov explains that this system of governance blocks the development of society and essentially prevents modernization. Whereas the USSR was a party-state, Putinism is based on quasi-democratic institutions. The regime also differs from the Soviet era as it lacks an ideology that governs them.

Taylor (2013) takes a different approach. He proposes that state capacity and state quality are two ideas that help explain Russian leadership. His conclusion is that "perhaps most important is whether Medvedev, Putin, or any other future leader can articulate a clear and appealing ideological project for the Russian state that will be embraced by officials" (Taylor 2013, 321). Putin has not decided to set a goal of "building a state with both high capacity and high quality," but has instead revived the "Russian Idea (i.e. the sphere of influence)" (Taylor 2013, 321). Taylor suggests this justifies a traditional service state, with Russian moving further toward a police state. Recent crackdowns on journalist freedoms are one example of moving toward increased capacity but less quality.

Taylor correctly proposes that authors who view Putin's contribution to Russian state building as positive generally fit into two lines of reasoning: during Putin's first reign Russia was in the beginning stages of state building; or the idea Russia can only be a strong state if it is a police state (Taylor 2013, 312). Both of these, along with Taylor's, do not fully tell the story of Putin's decision making. Taylor's ideas are still mired by statist ideas, or perhaps more accurately neo-statist ideas, defining state capacity as "the ability of a state to ensure the reliable implementation of its decisions by its own personnel" (Ibid). Taylor defines state quality as a term similar to good governance.

Sakwa (2010) rejects the idea of transitional democracy, semi-authoritarian democracy, and illiberal democracy, calling it "democracy with adjectives," and instead puts forth the idea that Russia is a dual state, which he defines as a constant struggle between the administrative state and the constitutional apparatus in the Kremlin. This creates a situation where democracy has been furthered, but at the same time authoritarianism does not disappear. This constant fighting was what made Medvedev gain power, but this permanent stalemate seems to have been won by Putin and a more authoritarian turn. 
Shevtsova (2010) uses some of Sakwa's "democracy with adjectives" when she describes Putin's Russia as imitation democracy that uses highly personalized rule embedded within propaganda. This began under Yeltsin rather Putin. Shevtsova suggests that Russia uses the ideals of the West for self-serving purposes where they differentiate themselves from the rest of Europe, something Russia feels is necessary after the fall of the Soviet Union and the failure of the Yeltsin experiment (Shevtsova 2010).

Zakaria (2014) proposes that Putin's Russia provides an alternative model to liberal democracy. Putinism provides a "new system and set of values" that are gaining a foothold in other European states which are slowly becoming disenfranchised with the European Union's recovery after the global financial crisis in 2008 (Zakaria 2014). Zakaria proposes that the Putinism has five major components: nationalism, religion, social conservatism, state capitalism and government domination of the media. This is in opposition to the Western values of individual rights, tolerance, cosmopolitanism and internationalism, and, according to Zakaria, Putinism is what sustains his popularity.

Nikolai Petrov argues that Putin has succeeded in consolidating power by stripping all jobs of any meaning except that of the presidency. Essentially what appear as institutes with power, all lays in the hands of presidential representatives. The result of this is a managed democracy. This includes personal power that is not kept in check as the institutes of government have been withered to nothing. This also allows for the government to manipulate the press and control elections. The regime thus cannot react to crises as "a lack of failsafe mechanisms prevents the authorities from realizing that they are making mistaken decisions" (Gorenburg 2011, 5). Ultimately Petrov believes this will lead to failure as the population will become less empathetic toward the leadership overtime.

Aleksandr Kynev suggests changes in party laws have created a "simulated multiparty system at the feudal, regional, and municipal levels, under the tight control of the executive branch" (Gorenburg 2011, 6). What Kynev sees in Russia are no real parties in the traditional sense. Instead, he believes the changes in law have allowed the government to control much of the regions within the Russian polity. The result is a semi-feudal system where a tightly-knit unit of men controls the interaction with the periphery states. Thus, the regional leaders have become more like yes-men to the state. As such, political conflict has increased and will continue to do so.

One set of theories that more effectively explains the diplomatic quagmire is analytical eclecticism introduced by Katzenstein and Sil (2004). This proposes that no one theory is analytically superior to another, and without using certain aspects of each theory reality cannot be articulated. He proposes a triad of the three "isms" which can explain policy articulation. 


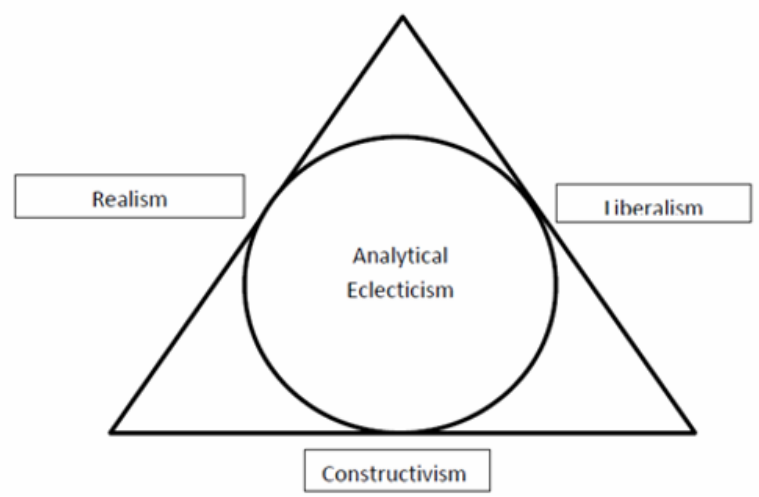

FiguRE 1. ECLECTICISM

Although its shortcomings are numerous, eclecticism has many uses. For instance, it attempts to incorporate the non-rationalist traditions of non-American scholars, and it also introduces rationalism to other traditions. It allows scholarship to link other social sciences to IR. However, conscious calculation of situations exists in all three paradigms, creating a situation where identity, ideas, and norms cannot be explored effectively. Unconscious calculation appears to temper diplomatic practice more than these explanations. Thus, let us turn to political sociology for an explanation of diplomatic practice in the CIS.

The resulting practice theory changes "the arrow of social action-from ideas to practice-and emphasizes how practices also shape the world and its meaning" (Pouliot 2010, 6). If we no longer observe through the looking glass of rationalism or collective identity creation it becomes apparent that agents act on preconceived knowledge. This theory clearly shows how some regional institutions have been successful, whilst others have not. In this way, the theory better explains why some diplomatic practice has been understandable whilst some has not.

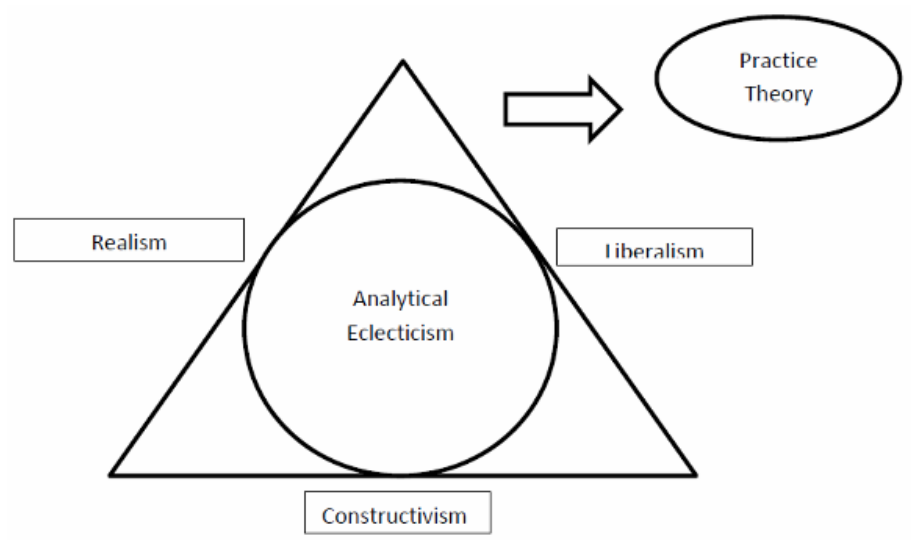

Figure 2. Practice THEORY 
In response to representation bias, Pouliot puts forth a theory based on Pierre Bourdieu's idea of practice. Practice theory contests that diplomacy is self-evident and the knowledge we bring to the table is inarticulate.

\section{NEW PUTINISM}

This paper offers an updated look at Putinism by creating a new image of Putin: New Putinism. As this paper will highlight, under Putin, Russia has evolved into a new polity based on different premises than previous leadership. Russian habitus in the European diplomatic field has ranged from doxic to hysteretic (harmonious to resentful). Nonetheless, over the last few decades it has been surprisingly harmonious. During the Cold War the relationship between Russia and the West, at least in regional diplomacy, was doxic as each side followed the innately learnt rules of the game. The Soviet Union knew not to cross some red lines, and the US knew not to antagonize the USSR. These rules kept the Cold War cold.

Yeltsin era diplomacy was also doxic due to each side knowing the symbolic order of relationships of domination. Yeltsin had accepted a smaller Russia, and looked inward for development. His expansionist desires appeared minimal, and the US respected and worked closely with him due to this. This homology changed with Putin. Putin's initial years in power were successful, largely due to economic growth. This was, however, highly unstable and unsustainable. Thus, he adapted and used his prior learning as a KGB operative to craft a new habitus. Much theorizing about Putin's ideology has discussed it in relation to a Tsarist vision (for example, Myers 2015). However, this remains to be seen. Meanwhile, what can be seen in the contemporary world is Putin's desire to return to an era where Russian influence in the region was much greater. This new diplomatic practice is termed New Putininsm and is based on five simple premises:

- Russian ethno-centrism: Russia has pivoted inward under Putin. Putin bases his ideas on Russian-ness: Russian people are the most important people to the state.

- Not being scared of the global West: Putin has little regard for the West. He has seen America first pivot to the Middle East and then to Asia. Putin sees little reason why it would not be possible to create a new fortress (iron curtain) around Russia that was essentially destroyed after the Cold War, and threatened when Georgia and Ukraine flirted with joining NATO and the EU.

- Secrecy: Putin is a former KGB operative, and innately applied the techniques he learnt to his leadership. This includes the idea of a "Collective Putin." For a long time it was believed that Post-Cold War Russia was run by two competing groups: technocrats and a small clique of ex-KGB operatives. The security veterans usually held the most power, but did not monopolize it. How- 
ever, recent action in the Crimea suggests that unilateral action by this "collective Putin (Putin plus the KGB clique)" (Faith 2014) is possible. This also makes Putin susceptible to act on imaginary threats that just do not exist. The KGB was notorious for acting on paranoia, and Putin's Russia appears to do the same.

- Disdain for multilateral institutions: Putin showed no desire to gain acceptance from international multilateral organizations before or during the Georgian or Ukrainian conflicts. For example, this includes not allowing the OCSE full access to Ukraine after the downing of Malaysia Airlines Flight 17 (MH17).

- The creation of a Russian sphere of influence: Russia's new-found resolve in annexing near-by countries is not entirely new. Transnistria in Moldova was invaded in a similar fashion to Abkhazia and South Ossetia. In fact the habitus of Yeltsin leadership was inward looking: toward a unified and strong Russia. With the election of Putin a new found resolve for annexation of the "near abroad" began- a new Russian sphere of influence.

These premises have combined to create a Russia with a new resolve. New Putinism has become the habitus of Russia, and the following section will use the case studies of Georgia and Ukraine to trace the reasons for the aforementioned premises.

\section{Thawing the Frozen Conflicts: Russia's Invasion of Georgia and Ukraine}

What made Russia decide to thaw out the frozen conflicts in Georgia and Ukraine? Was it opportunistic land grabbing? Was it to do with oil? We propose through the lens of New Putinism that it was all to do with the habitus of the Russian polity.

Georgia and Ukraine have been chosen as comparative case studies for many reasons. Firstly, they both went through what has been coined "a color revolution." Georgia had its Rose Revolution in 2003, and Ukraine had its Orange Revolution in 2004-2005. These revolutions are not what most people would refer to as a classical revolution. Instead colored revolutions use non-violent civil resistanceincluding strikes and demonstrations-against leaders they consider corrupt and/or authoritarian (Lane 2009). A colored revolution advocates democracy, pressuring to change the government. The revolutions arose in Georgia and the Ukraine following disputed elections. The Rose Revolution began after the disputed election in 2003 and led to the overthrow of Eduard Shevardnadze who was replaced by Mikhail Saakashvili after elections in March of 2004. The Orange Revolution followed the disputed second round of the Ukrainian Presidential election in 2004. The round was annulled and repeated after numerous demonstrations. The leader of the opposition, Viktor Yushchenko, was acknowledged as President, ousting Viktor Yanukovych. 
The Rose and Orange Revolutions changed the habitus of Georgia, Ukraine, and Russia. The revolutions attempted to end regimes considered authoritarian and/or illegitimate, and tried to instill working democracies. Whether they were successful or not is hardly relevant to a practical ontology. What is important, however, was the change in leadership style and democratic methods that were practiced after leadership transition (both became more liberal, at least superficially). These revolutions led to a change in habitus amongst the Russian elite. Similarly, both states have flirted with joining the EU, NATO, and western powers. This was largely a result of the colored revolutions. After each felt they had democratized they tried to persuade other states in the region, and the world, to help them institutionalize their opposition to previous Russian dominance. Russia began to feel threatened as Georgia and the Ukraine looked for other avenues for security. They would try to find this in NATO, and more broadly from the West.

Before proceeding it is critical to mention the reign of Dmitry Medvedev. The Medvedev and Putin era has been described as "Rokirovka," the Russian name of castling in chess. This essentially means that Medvedev just took Putin's place, whilst Putin retained all the power in the Duma. For the purpose of this paper we presume this to be the case. For a more in-depth analysis of this see Meyer's The New Tsar.

Putin in many senses acts in paranoia rather than facts. This can also be attributed to his habitus. If we contrast Medvedev and Putin's runs in the presidential positions this is quite pronounced. Medvedev, with no KGB background, did not appear to act on impulse or paranoid impulses. When Putin once again ascended to the Presidency he did. Medvedev appeared to respond to public sentiment, for example when they protested over the imprisonment of Khodorkovsky. Putin made outrageous accusations about Khodorkovsky, including the possibility he tried to have people murdered. This was a strategy to make sure he would be prosecuted. Medvedev seeing this as terrible for the government in the eyes of an increasingly political public, denounced Putin for the first time.

\section{Georgia}

During the Soviet era South Ossetia was an autonomous republic. Following the dissolution of the Soviet Union, it became part of the Georgian polity. When Georgia tried to distance itself from Moscow, South Ossetia attempted to gain independence from Tbilisi. This sparked the 1991-1992 Georgian-South Ossetian Civil War. The Georgian army was largely unorganized and was promptly defeated by a combination of secessionist Ossetians, Russians from the Russian Federation, and former Soviet Troops who were left there after the dissolution of the USSR. The following year Georgia staged a war with another breakaway region, Abkhazia, to try and stop it from seceding. This also ended in defeat for Tbilisi. As a result, 
Russian peacekeeping forces remained in the area under the terms of cease-fire agreements. These agreements turned into frozen conflicts that were largely forgotten by the western press. It was acceptable to the Western habitus as long as no killing occurred and as long as they stayed frozen.

After the Rose Revolution and under Mikhail Saakashvili, Georgia essentially proposed a model of governance in opposition to Putin's. This new hubris, developed in the post-Soviet field, was essentially pro-western nationalist rhetoric mixed with economic liberalization. This model did reduce corruption and gangsterism (Judah 2013, 163). Thus, when other revolutions occurred in the near-aboard this new model of governance became an alternative. Having an opposing ideology in the Russian Sphere of influence was not acceptable to Putin.

The Georgian War in 2008 was initiated by Georgia. Tbilisi attacked the breakaway province of South Ossetia with the belief that reuniting the two countries would be a positive for the new Saakashvili government. Russia reported that Georgia had attacked the Russian peacekeepers in the breakaway region and was committing genocide. Tbilisi asserted that Russian forces had moved into South Ossetia and were compelled to act accordingly.

Judah suggests the Georgian War was "the collision of three hubristic projects. The first was Georgian hubris that it could crush two Russian mini-client sates without consequence. The second was the American hubris that it could build client states out of core ex-Soviet states and integrate them into NATO without consequences. The third was Russian hubris that it had a veto on the foreign policy choices of Georgia and Ukraine and could crush, invade and depose the leadership of an American client state without consequences" (Juda 2013, 164).

This war did not mark the start of Cold War 2.0. However, what it did start was a re-orientation of ideology in Russia. Charles King proposes that this war marked the return of Russia to Tsarist ways. The Tsars "came to see the great powers as self-interested and manipulative, and busy either dismantling solid countries or propping up decrepit ones" (King 2008). Thus, Russia withdrew from its partnerships with Europe and reverted to a form of "wary cynicism, and introverted nationalism, and a belief in raw power as the hallmark of international politics" (King 2008). The pattern of Russian cooperation with, and then withdrawal from, European partnerships began with the Crimean War and repeated itself until the end of the Cold War. Thus, King suggests that it was inevitable that a negative relationship would occur sometime after the Cold War. The European-Russian relationship once again faltered in 2008 and the South Ossetian Crisis "will mark a time when Russia came to disregard existing international institutions and began, however haltingly, to fashion its own" (King 2008).

The Russo-Georgian War changed this. It differed from previous engagements with local states as Russia did not follow the rules of the field. In the past "local military commanders stepped in between warring parties and brought a swift end 
to fighting," but in Georgia Russia attempted to "bypass established channels of conflict resolution and unilaterally change the boundaries of another UN member state" (King 2008). Russia further changed the rules by unilaterally recognizing Abkhazia and South Ossetia as states on August 26. They have only gained recognition from the following nations: Russia, Nicaragua, Venezuela and Nauru.

This conflict can be seen as the start of New Putinism. First the war was initiated on two premises: Russian ethno-centrism, and subverting attention away from Russian economic weakness. Putin sent his troops into Georgia based on the premise that Russian speakers (i.e. those in the Russian sphere) were being attacked. South Ossetia and Abkhazia had for a long time tried to be brought into this sphere by granting those in break-away regions Russian passports, and also deporting Georgians. This patronage aided the secessionist movements of 2008.

The invasion of Georgia also highlights the fall of the Russian economy. Putin came to power with the promise of raising living standards. Initially this worked as sales of oil, gold, aluminum, and other extractable materials spiked in price allowing for exponential growth from 2000-2007 (Frum 2014). The spike legitimized Putin's rule, but quickly unraveled with the global financial crisis of 2008. "Onethird of Russia's foreign-currency reserves evaporated in a few months in an effort to protect the ruble," and "The Russian stock exchange lost 80 percent of its value" (Frum 2014). Putin could no longer be legitimized by this. One alter-native would be invading South Ossetia and Abkhazia.

The Russo-Georgian conflict showed that Russia was willing to intimidate the region, and also had the means to annex other states. Tellingly, this war revealed Russia's disdain for international multilateral organizations. What made Georgia different to other wars in the region was Russia launching an attack on a neighboring state without securing international support or "even developing a public relations strategy" (King 2008). This allowed Georgia to win the propaganda war, something Russia would change in Ukraine. Nonetheless, the war was popular in Russia. According to a poll by the Levada Centre, almost 80 percent of Russian respondents supported the invasion of Georgia (King 2008). Just over half blamed Georgia for starting the war, and many identified the US desire to encroach on the region as the root cause of the war. Thus, even at this early stage of New Putinism domestic propaganda was working. Judah suggests following the start of the war massive posters were put up in Moscow in Support of South Ossetia. This included the slogan "Tskhunvali we are with you." Judah claims that "Kremlin intellectuals began to talk, behind closed doors, of 'Putin's historical defeat of an American client state"" (Judah 2013). Just after this marked the height of Putin's popularity at around 83 percent (Ibid).

\section{Ukraine}

Judah makes an interesting observation regarding Russia and Ukraine: 
For Russians, Ukraine is not really abroad. The language, history and culture are so close and so shared, and families so mixed up, that a trip there 'does not count as being abroad.' This translates to a belief by swathes of the establishment that Ukraine is not a 'true' state and cannot be permitted to be 'severed from Russia.' This goes as far as the hope of eventual reunion ... Stopping Ukrainian NATO membership is essential to Russian hopes for maintaining a sphere of influence or reintegrating with the two Slavic exSoviet states (Judah, 2013, 57).

In February 23, 2014, the public focus was on the final medal tally of the Sochi Winter Olympics. Concurrently, what appeared like unmarked Russian soldiers were entering Crimea. Although the Olympic analogy may be nothing more than coincidence, it does highlight one fact: that Russia has unilaterally redrawn the map of Europe twice in a stretch of six years.

The chaos that has engulfed Ukraine began in November 2013 when thousands of Ukrainians took to the streets to protest against former President Viktor Yanukovych. Yanukovych had begun to move away from an associate agreement with the EU, and instead sought closer relations with Russia. These protests would come to be known as Euromaidan (literally Eurosquare). Demonstrations slowly moved to civil unrest, calling for the embattled president to resign. This prompted Yanukovych to adopt anti-protest laws, followed by fighting between government forces and civilians. Due to this spiral into anarchy Ukrainian members of parliament set an election for May 25, after Yanukovych fled to Russia (Balmforth and Zinets 2014). This election was won by Petro Poroshenko.

Simultaneously, an invasion began in Crimea. It culminated when exiled president Yanukovych requested that Putin mobilize the Russian military "to establish legitimacy, peace, law and order, stability and defending the people of Ukraine" (NBC News). Putin responded and deployed troops the next day, gaining full control of Crimea. Initially, Putin did not admit these troops were Russian. The "Little Green Men" (or Polite People as they were termed in the Russian press) that first appeared in Crimea, and later in the Donbas, were a manifestation of Putin's secretive habitus (Myers 2015). These soldiers bore no insignia and appeared in the region in an instant. However, their thinly veiled identity was quickly exposed as being part of the Russian Special Forces. Nonetheless, Putin did not publicly acknowledge this until weeks after the invasion had begun. This tactic was used to confuse governments in the region and worldwide, and also to remove any culpability that Russia could face. It was also a return to the KGB habitus Putin innately learnt. Rather than fighting in the open, a thinly veiled force blocked off Ukrainian forces, and helped annex Crimea.

The Russian forces continued to take over key political areas of Crimea which laid the foundation for a referendum on March 16. This referendum asked 
two questions: Do you support re-joining Crimea with Russia as a subject of the Russian Federation? And do you support restoration of the 1992 Constitution of the Republic of Crimea and Crimea's status as a part of Ukraine? (BBC News). This was illegitimate by Ukrainian law, as Article 135 of the Ukrainian constitution indicates that the Crimean constitution must be approved by the Ukrainian parliament. Nonetheless, the referendum was held on March 16 with no non-aligned, transparent observers present. Neither the Organization for Security and Cooperation in Europe (OSCE) nor the UN was present to verify things. Russia once again unila-terally took over territory, showing no regard for international organizations.

Citizens were suddenly in a different country. The flags changed instantly, as did the names on the parliament buildings. The support for this referendum was hard to discern. The Russian media said that there was an 80 percent turnout with 97 percent voting in favor of becoming part of Russia. This number is highly unlikely for many reasons, none more so than the demographics of the region where around 12 percent of the population are Tartars, and 24 percent are Ukrainian (Speri 2014). This puts doubt on the official numbers. However as with many things Putin, the preposterous can make sense. What followed was similar to Georgia, but had even greater significance as Crimea was claimed to be part of the Russian Federation. Putin signed off on laws formalizing Crimea as part of Russia, and Crimea now uses the ruble and runs on Moscow time. All of it done without any international approval or anything resembling international legal legitimacy.

Further unrest began in the Donetsk Oblast during March 2014. It began with pro-Russian citizens staging protests and eventually occupying many government buildings including the City Hall and the regional administration building. This led to fighting between locals and Ukrainian military forces. Many other actors have also been present in this ongoing conflict including: Russian Special Forces, Cossack regiments, Ukrainian national forces, and other rag-tag groups of pro and anti-Russians. This led to the May 11 Referendum where the majority of those voting were in favor of ceding from Ukraine. Once again no observers were present and there were reports that as much as 100,000 ballots ticked yes were sent to the region before the ballot (Speri 2014). Armed militia were also present, intimidating many potential voters.

Whilst it appears to be a purely localized issue it is not. Following similar logic to one that was used in Georgia and Ukraine, Russia has been accused of "an anti-Ukrainian plan being put into operation ... under which foreign troops will cross the border and seize the territory of the country" (Balmforth and Zinets 2014). However, this conflict is different as it has been greatly condemned by many observers, and it appears Poroshenko has a policy to end the conflict as soon as possible. Resistance in Crimea was minimal, but in Eastern Ukraine there appears to be greater resistance as the Ukrainian government became more organized. 


\section{The Misreading of Russia}

IR orthodoxy has limited appeal when explaining foreign policy articulation in Russia and the former Soviet space. Realist explanations in particular have fallen flat. Realist sentiments include the idea that Russia is simply returning to great power politics. This revolves around the idea that Russia will provoke external conflicts much like it did during Tsarist and Communist eras. This can be a persuasive argument to many, and once again spares policy makers from losing face. However convincing this argument may be, why did observers fail to predict this revival? As shown earlier, Russia's five-day military invasion in Georgia could have been an obvious signal of new-found resolve. Instead realists, and much of the US and EU policymaking community, largely supported the US reset policy (Shevtsova 2014b). This began with Hilary Clinton giving Sergey Lavrov a reset button that hilariously spelt reset wrong (instead writing overload) in Russian. These policymakers proposed that the US and Russia had shared interests, and assumed that Russia could contribute to the US achieving goals in the region. The habitus of hubris has become the norm.

Another normalist interpretation is by Anne-Marie Slaughter. She suggests that "The United States would do well to tone down its sanctimony. Putin's annexation of Crimea violated international law. But so did the U.S. invasion of Iraq and the NATO intervention to protect Kosovo, even if the latter was, to many, including me, a legitimate violation" (Quoted in Shevtsova 2014c). Thus, shall all states ignore rules and norms that have been created over the years? Of course states should not do this. The conclusion that is drawn is Ukraine can only succeed as a state if it becomes a bridge between Russia and the EU. This Finlandization is meant to make states in the region flourish, with conflict being minimized (Shevtsova 2014 b). However, states are not flourishing. The realist logic is flawed, and in many ways helps legitimize Putin's position in the region, as it is creating new myths. Promoting Ukraine as a failed state, claiming that Russia is now becoming a great power once again, and that it has an historical right to intervene in its backyard, promotes Putin as a legitimate leader with serious interests. This glosses over the issue of the Tatars in Crimea, and other minorities in Ukraine.

George Friedman has been of the opinion that the US and other western states have "viewed Russia through the prism of the 1990s or even earlier, when the Russian military was in shambles and the Russian government was paralyzed" (Friedman 2008). This has essentially led other states to miscalculate Russia's intentions in the region. The assumption was that Russia would no longer strike militarily. This was mistaken, and has led to hysteresis.

Many Ukrainian observers have expressed the idea that Putin is not in his right mind. Former US Secretary of State Madeleine Albright proposed "I think [Putin] either does not have the facts, or he is being fed propaganda .... Putin is, in 
many ways, I think, delusional about this" (Quoted in Shevtsova 2014c). German Chancellor Angela Merkel added Putin is "delusional" and "living in another world" (Ibid). However, upon any analysis it becomes apparent that these leaders are living within their own habitus. If Putin is indeed one of these things, delusional or living in another world, then why did no observers propose this until now? Why did Putin select this moment to extend his influence? If Putin literally just lost his mind then these explanations are plausible, but this seems highly unlikely. Instead such an analysis of Putin essentially allows policy makers to make asser-tions that are mistaken. Shevtsova suggests "if the West is dealing with an unex-pected deviation from the norm, this means that the previous policy toward Russia was essentially correct" (Ibid). We argue that it is a habitus of forgetfulness and hubris. Have policymakers forgotten about Georgia in 2008. It appears that a habitus of not caring about the CIS region is present, a dangerous precedent for the region.

Using Bourdieu methodology, it appears difficult for a state to change its habitus. Indeed, using examples from the US shows their thinking about Russia is at least 15 years in the past. The only way to change this is through further innate learning, which is time consuming. US orthodoxy, and in turn the majority of IR orthodoxy around the world, continues to teach realism as the be all and end all of diplomacy. This practice deems to be unhelpful.

Shevtsova proposes that debunking a few myths before they become crystalized in western habitus will be useful. The Ukrainian conflict is not a signal of a renewed Cold War. Indeed, it is no longer a clash of ideology between the West and Russia. It is instead Putin attempting to undermine the "remaining elements of the post-Yalta order" (Shevtsova 2014c). This order was instituted to try and prevent annexation and wars occurring in the region. Putin is now trying to re-interpret the rules in a way that was unthinkable during the doxic Cold War.

Another myth prevailing in the media is that Russia was spontaneous in responding to the Ukrainian crises. New Putinism has been in the making for years with Georgia and Ukraine being part of Putin's preventative habitual doctrine. This doctrine ensures Putin's survival by restoring the military and creating a mental fortress among the Russian population. This began with excursions into Georgian and intensified when the recession become large enough that it could adversely affect the Putin regime. Militarism has been restored before people take to the streets like they did in the color revolutions, and also in Euromaidan.

To help maintain the status quo the Russian regime has resorted to revanchism and irredentism. This has created a situation where Russia is slowly losing patronage with the West, whilst attempting to gain support at home. Russia may have resorted to this as the "collective Putin" could not envision any other policy to help maintain the status quo. Putin has invoked the ideas of a new Russian sphere, a revanchist idea that Europe tried to remove in the latter half of the 20th century.

The policy of de-stabilization is deliberate. The Kremlin has created unstable 
situations to try and instigate high-level talks where they can be a main actor. If a policy regarding the reconstruction of Georgia or Ukraine was founded, they would no doubt gain a legitimate role. Unfortunately for Putin, his "crisis management" has been largely unpalatable to other states. The technique is akin to knocking someone out then helping then regain consciousness. However, this technique has not been allowed to be normalized by other states.

The policy of invasion and annexation has worked for Putin. His popularity has spiked following each conflict. However, as the Russo-Georgian War has shown use of external conflicts only have a transient effect. Excursions are quickly forgotten and the leadership must look for a new place to invade and/or annex. Following the annexation of Crimea Sergei Lavrov suggested that "if [the west] are willing to accept the first reality, then they will definitely have to accept another one" (Ibid). Lavrov was promoting the idea that if the West was willing to accept the Ukrainian government, then they must accept the annexation of Crimea. This is not dissimilar to the case of Georgia when Russia annexed South Ossetia and Abkhazia. If the West were to accept Georgian leadership after the Rose Revolution then these annexed lands should also be recognized. Lavrov is reiterating the new Russian habitus; one where the Western powers are weak, unwilling to fight back, and not willing to fully help a non-NATO member. This was reinforced in April 12 when Lavrov tweeted "The world order is being restructured. This is painful process. But the West has to accept it" (Ibid).

The use of referendums has become a staple of New Putinism. Russian Presidential Decree No. 1260 and 1261 unilaterally recognized Abkhazia and South Ossetia, respectively, as part of the Russian Federation. Similarly, Putin signed a decree annexing Crimea on March 17, 2014. Donetsk is, at this moment, somewhat different as it has not formally been recognized by Russia.

The prevailing habitus is so ingrained in the Russian polity that a retreat from Crimea, Eastern Ukraine, South Ossetia, or Abkhazia would be tantamount to political suicide. In this sense Russian leadership is diverging further away from the West. The West's response is largely one of hysteresis. Western states have largely responded only to tactical moves made by Russia, and have misread the underlying logic of Putin. US orthodox thinking has made responses slow and ineffective. The policies of "engagement, accommodation and imitation" are relics of a realist era where the rules of the game were known and followed by all; a harmonious time. The post-Cold War era is over. But the inability to realize change is telling. A Western habitus based on realism mixed with neoliberal economics has failed to understand a diverging Russia.

\section{CONCLUSION}

This paper has shown how expectations towards the world order have changed since the turn of the millennium. Whereas in the past NATO and Western powers 
could compel Russia to act in subordinate fashion, they can no longer compel it to do so. Starting with Kosovo, gaining momentum after the Russo-Georgian War and peaking in the events of 2014 in Crimea, Russian diplomacy and security practice has changed. Russia does not follow the West, and largely ignores signals from the West. Instead, after years of NATO expansionism and hysteresis in diplomatic relations Russia now follows its own script.

The chessboard analogy can be used to explain Putin's newfound habitus, and also that of other states in the region. The US President is always thought to be playing multiple games of chess on a single chessboard, looking over many games at once and being defensive in all games (Brzezinski 1997). Other states in the region play one game of chess or potentially play a different form of chess; for instance checkers. Although similar, the rules of the game are slightly different. Russia essentially has flipped this board over. No longer willing to play a game within the field of European diplomacy, Putin has crafted a habitus where the operational procedures that existed under Yeltsin no longer apply. Thusfar, the West has failed to change a habitus that is still stuck in either a Cold War or Yeltsin era. In the US, this is understandable as their main analysts and those in positions of power have had this habitus validated by Russia for years. Ukraine under Poroshenko is a slightly different prospect. He has shown a habitus much different from the US or others. Having been part of the Orange Revolution and having seen Georgia go through similar stages, Poroshenko is unwilling to talk to the breakaway Eastern regions. This would legitimize their secessionist ambitions. Instead he has begun counter-insurgency operations in the region.

Practice theory has shown that "relational dynamic perpetuates symbolic fights and domination patters" (Pouliot 2010, 236). This is patently obvious in these two case studies. There may be peaceful ways to solve conflict, and fortunately these two conflicts have been relatively low intensity especially compared to previous wars in the region. However, fundamental practices of everyday life have dictated the diplomatic behavior of Russia and other states in the region. Using this theory could be useful for further analysis. For instance, using this theory could predict that Putin's Russia may try to encroach on the Baltics and Moldovia, and possibly further expansion into the Kirill Islands. However, Putin has recently made concessions in Estonia, Latvia and China. If further analysis using practice theory is done, we believe the future of the region could become clearer for those who follow the region.

\section{REFERENCES}

Adler, E. and M. Barnett. (eds.) 1998. Security Communities (No. 62). Cambridge University Press.

Adler, E. and V. Pouliot. 2011. International Practices. International Theory 3(1): 
$1-36$

Akkieva, S. 2008. The Caucasus: One or Many? A View from the Region. $\mathrm{Na}$ tionalities Papers 36(2): 253-273.

Balmforth, Richard and Natalia Zinets. 2014. "Protests in Eastern Ukraine Aimed at Bringing in Russian Troops, Warns PM." In Reuters, last modified April 7 2014, accessed February 12, 2014, http://www.reuters.com/article/2014/04/ 07/ us-ukraine-crisis-storm-idUSBREA350B420140407

Beacháin, Donnacha Ó. 2009. "Roses and Tulips: Dynamics of Regime Change in Georgia and Kyrgyzstan." Journal of Communist Studies and Transition Politics 2(2/3): 199-226.

Beer, Daniel. 2009. "Russia's Managed Democracy.” History Today 59(5): 37.

Black, Stephen. 2008. "What Comes After the Russo-Georgian War? What's at Stake in the CIS." American Foreign Policy Interests: The Journal of the National Committee on American Foreign Policy 30(6): 379-391.

Brzezinski, Zbigniew. 1997. The Grand Chessboard: American Primacy and Its Geostrategic Imperatives. New York: Basic Books.

Bullough, Oliver. 2014. "The Party's Over for Crimea, but the Hangover Will Linger for a Long Time," In New Republic, last modified March 23, 2014, accessed November 27, 2016, http:/www.newrepublic.com/article/117123/what-2008russo-georgia-war-foretells-about-crimeas-future

De Waal, Thomas. 2013. "So Long, Saakashvili." In Foreign Affairs, last modified October 29, 2013, accessed November 27, 2016, https://www.foreignaffairs. com/articles/russia-fsu/2013-10-29/so-long-saakashvili

Faith, Ryan. 2014. "Why Putin Will Get Everything He Wants in Crimea." In Vice News, last modified March 3, 2014, accessed November 27, 2016, https:// news.vice.com/article/why-putin-will-get-everything-he-wants-in-crimea

Friedman, George. 2008. "The Russo-Georgian War and the Balance of Power." Geopolitical Weekly, last modified April 12, 2008, accessed November 27, 2016, https://www.stratfor.com/weekly/russo georgian war and balance power

Frum, David. 2014. "What Putin Wants," In The Atlantic, last modified May 21, 2014, accessed November 27, 2016, http://m.theatlantic.com/magazine/arch ive/2014/06/what-putin-wants/361622/

Gorenburg, Dmitry. 2011. "The Nature of the Russian Political System: Editor's Introduction." Russian Politics and Law 49(2): 3-7.

Herd, G. P. 2001. "Russia and the Politics of 'Putinism." Journal of Peace Research 38(1): 107-112.

Hopf, Ted. 2002. Social Construction of International Politics: Identities and Foreign Polices, Moscow, 1955 and 1999. Ithaca: Cornell University Press.

Jackson, Peter Review in Catherine Lu and Diane Labrosse (ed). 2011. "H-Diplo/ ISSF Roundtable Review of Vincent Pouliot's International Security in 
Practice: The Politics of NATO-Russia Diplomacy." Roundtable: 2-5.

Kagan, Robert. 2014. "Superpowers Don't Get to Retire: What our Tired Country Still Owes the World." In New Republic, last modified May 26, 2014, access

November 27, 2016, https://newrepublic.com/article/117859/superpowers-do nt-get-retire

Kaplan, Robert D. 2000. "Where Europe Vanishes." In The Atlantic, last modified November 2000, accessed November 27, 2016, http://www.theatlantic.com/ magazine/archive/2000/11/where-europe-vanishes/306460/

Katzenstein, Peter and Nobuo Okawara. 2001. "Japan, Asian-Pacific Security, and the Case for Analytical Eclecticism." International Security 26(3).

Keck, Margaret E. and Kathryn Sikkink. 1998. "Activists beyond Borders: Advocacy Networks in International Politics." Ithaca, New York: Cornell University Press.

King, Charles. 2008. "The Five-Day War: Managing Moscow after the Georgian Crisis." Foreign Affairs. 87(2): 2-11.

Kissinger, Henry. 2014. "How the Ukraine Crisis Ends." In The Washington Post, last modified March 5, 2014, accessed November 27, 2016, http:/www.wa shingtonpost.com/opinions/henry-kissinger-to-settle-the-ukraine-crisis-startat-the-end/2014/03/05/46dad868-a496-11e3-8466-d34c451760b9 story.html Kramer, David J. 2014. "Action, Not Worlds, Needed for Ukraine." In The Washington Post, last modified April 22, 2014, accessed November 27, 2016, https://www.washingtonpost.com/opinions/action-not-words-needed-for-ukr aine/2014/04/21/046a783e-c968-11e3-93eb-6c0037dde2ad story.html?utm term=.cc60fa3eb49d

Kramer, David J. and Andrew Higgins. 2014. "Ukraine Forces Storm a Town, Defying Russia." In The New York Times, last modified April 14 2014, accessed November 27, 2016, http://www.nytimes.com/2014/04/14/world/ europe/ukraine-forces-and-pro-russian-militants-battle-over-local-police-stat ion.html? $\mathrm{r}=1$

Judah, Ben. 2013. Fragile Empire: How Russia Fell In and Out of Love with Vladimir Putin. New York: Yale University Press.

Kremlin. 2014. "Executive Order on Recognising Republic of Crimea," In Kremlin, last modified March 17, 2014, accessed 17 March 2014. http://en.kremlin.ru/ events/president/news/20596

Lane, David. 2009. “'Colored Revolution' as a Political Phenomenon.” Journal of Communist Studies and Transition Politics 25(2/3): 113-135.

March, James G. and Johan P. Olsen. 2004. The Logic of Appropriateness. Arena. Mearsheimer, John. 2001. The Tragedy of Great Power Politics. New York: W.W. Norton and Company.

Mearsheimer, John. 1990. "Back to the Future: Instability in Europe after the Cold War." International Security 15(1): 52. 
Mead, Walter Russell. 2014. "Playing Putin's Game," In The American Interest, last modified April 15, 2014, accessed November 27, 2016, http:/www.theamerican-interest.com/wrm/2014/04/15/playing-putins-game/

Myers, Steven Lee. The New Tsar. Knopf: London, 2015.

Pouliot, Vincent. 2008. "The Logic of Practicality: A Theory of Practice of Security Communities." International Organization 62 (2): 257-288.

Pouliot, Vincent. 2010. International Security in Practice: The Politics of NATORussia Diplomacy. Cambridge and New York: Cambridge University Press.

Reed-Danahay, Deborah. 2005. Locating Bourdieu. Bloomington: Indiana University Press.

Reddaway, Peter. 2012. “Is Putin's Regime Becoming More Like Brezhnev's? Some Similarities and Differences." Demokratizatsiya-The Journal of PostSoviet Democratization 20(2): 97.

Reshetnikov, Anatoly. 2011. "Great Projects Politics in Russia: History's Hardly Victorious End." Demokratizatsiya-The Journal of Post-Soviet Democratization 19(2):151-175.

Saakashvilli, Mikhail. 2014. "Let Georgia be a Lesson for What Will Happen to Ukraine," In The Guardian, last modified March 14, accessed November 27, 2016, https:/www.theguardian.com/commentisfree $/ 2014 / \mathrm{mar} / 14 /$ georgia-les son-for-ukraine-crimea-referendum-trick

Sakwa, Richard. 2011. "The Clash of Regionalisms and Caucasian Conflicts." Europe-Asia Studies 63(3): 467-491.

Sakwa, Richard. 2010. The Crisis of Russian Democracy: The Dual State, Factionalism and the Medvedev Succession. Cambridge: Cambridge University Press.

Shevtsova, Lilia. 2010. Lonely Power: Why Russia Has Failed to Become the West and the West is Weary of Russia. Washington: Carnegie Endowment for International Peace.

Shevtsova, Lilia. 2014a. "Bravo, Ukraine, Bravo." In The American Interest, last modified May 26, 2014, accessed November 27, 2016, http://www.the-ame rican-interest.com/shevtsova/2014/05/26/bravo-ukraine-bravo/

Shevtsova, Lilia. 2014b. "Obama Blinks." In The American Interest, last modified June 3, 2014, accessed November 27, 2016, http://www.the-american-inte rest.com/2014/06/03/obama-blinks/

Shevtsova, Lilia. 2014c. "The Putin Doctrine: Myth, Provocation, Blackmail, or the Real Deal?." In The American Interest, last modified April 14 2014, accessed November 27, 2016, http://www.the-american-interest.com/articles/ 2014/04/14/the-putin-doctrine-myth-provocation-blackmail-or-the-real-deal/

Spiegel Staff. "The Opinion Makers: How Russia is Winning the Propaganda War." In Spiegel Online, last modified May 30 2014, accessed November 27, 2016, http:/www.spiegel.de/international/world/russia-uses-state-television- 
to-sway-opinion-at-home-and-abroad-a-971971.html

Speri, Alice. "Division Runs Deep in Donetsk, Mirroring Ukraine's Split," In Vice

News, last modified March 8, 2014, accessed November 27, 2016, https:// news.vice.com/article/division-runs-deep-in-donetsk-mirroring-ukraine-s-split Stepanova, Ekaterina. 2008. "South Ossetia and Abkhazia: Placing the Conflict in Context." SIPRI Policy Brief. Stockholm: Stockholm International Peace Research Institute (SIPRI).

Taylor, Brian D. 2013. State Building in Putin's Russia Policing and Coercion after Communism. Cambridge: Cambridge University Press.

Wendt, Alexander. 1998. "On Constitution and Causation in International Relations." Review of International Studies 24: 101-117.

Wendt, Alexander. 1998. Social Theory of International Politics. New York: Cambridge University Press.

Vartanyan, Olesya and Ellen Barrymarch. 2004. "If History is a Guide, Crimeans' Celebrations May be Short-Lived." In New York Times, last modified March 18 2014, accessed November 27, 2016, http://www.nytimes.com/2014/03/19/ world/europe/south-ossetia-crimea.html? $\mathrm{r}=0$

Wood, Andrew. 2014. "Slobodan Putin." In The American Interest, last modified May 5, 2014, accessed November 27, 2016, http:/www.the-american-intere st.com/articles/2014/05/05/slobodan-putin/

Zakaria, Fareed. 2014. "The Rise of Putinism." In The Washington Post, last modified July 31, 2014, accessed November 27, 2016, http://www.washington post.com/opinions/fareed-zakaria-the-rise-of-putinism/2014/07/31/2c9711d618e7-11e4-9e3b-7f2f110c6265 story.html

Zürcher, C. 2007. The Post-Soviet Wars: Rebellion, Ethnic Conflict, and Nationhood in the Caucasus. New York, NYU Press. 